\title{
Reflexões sobre a imprensa no Brasil de 1808
}

\author{
Marialva Carlos Barbosa
}

\section{Resumo}

Nesse artigo fazemos ampla reflexão sobre as idéias que têm dominado os estudos históricos sobre jornalismo no Brasil, governados a maioria das vezes pela idéia de gênese. Optamos também por analisar mais detidamente a Gazeta do Rio de Janeiro, considerada na visão tradicional da história do jornalismo como um periódico áulico e que defendia exclusivamente os interesses da Coroa Portuguesa. Olhando detidamente o jornal, pode-se reconstruir os sistemas de comunicação no Rio de Janeiro nos idos de 1800.

Palauras-chave:

Século XIX, Jornalismo, Gazeta do Rio de Janeiro

\section{Reflections about the 1808 Brazilian press}

\section{Abstract}

In this article we widely reflect over the ideas that have dominated historical studies on journalism in Brazil, mostly governed by the idea of genesis. We also opted to analyze more accurately the Gazeta do Rio de Janeiro, considered in the traditional history of Brazilian journalism as a courtly periodical that exclusively defended the interests of the Portuguese Crown. Taking a nearer view of the publication, it is possible to reconstruct the systems of communication in Rio de Janeiro in the far-gone 1800.

\section{Sobre a autora}

Doutora em História, professora do Programa de Pós-Graduação em Comunicação da Universidade Federal Fluminense, pesquisadora do CNPq. mcb1@terra.com.br
Key words:

Nineteenth century, Journalism, Gazeta do Rio de Janeiro 
A idéia de início primordial fornece uma espécie de senha para os estudos históricos. Há uma afã para saber como tudo começou ou como tiveram início os tempos fabulosos do começo. Os estudos sobre imprensa no Brasil, seguindo essa tendência, discutem qual teria sido, de fato, o primeiro jornal brasileiro: se a Gazeta do Rio de Janeiro, que começou a circular em 10 de setembro de 1808, portanto, três meses depois da chegada da Família Real ao Brasil, ou o Correio Braziliense, editado em Londres, desde junho daquele ano, por Hipólito José da Costa.

Outra questão discutida diz respeito ao atraso com que se implantou no país o jornalismo, de maneira particular, e a impressão, de maneira mais geral. Comparando esse processo com outros países da América Espanhola, procura-se justificar as razões desse atraso em função de fatores culturais, econômicos e políticos que teriam retardado o início da imprensa no Brasil.

Há ainda alguns estudos que enxergam a atividade jornalística desde tempos imemoriais. Assim, as cartas de Pero Vaz de Caminha, os manuscritos de circulação restrita, entre multiplicidades de exemplos, seriam práticas jornalísticas ${ }^{1}$. Nessa suposição exacerbada, é jornalismo tudo aquilo que é inscrito e divulgado, mesmo que não se tenha uma ação efetiva no espaço público.

Essas interpretações são tributárias de uma corrente de idéias que faz da história o lugar reflexivo do qual emerge o passado integralmente. É como se os documentos expressassem a realidade passada e que ao olhá-los e descrevê-los traríamos esse passado como realidade absoluta para o presente. Um passado que de fato aconteceu.

A segunda teia de idéias contida nessas análises refere-se à concepção de procurar as razões, as causas dos processos históricos a partir de uma ótica que privilegia a interpretação do passado pelos valores do presente. Razões sociais, econômicas, políticas - como se fossem instâncias separadas do mundo social - explicariam por si só os motivos da não circulação, antes de 1808, de jornais impressos no Brasil. Claro está que as proibições à circulação dos impressos impossibilitavam os trabalhos de impressão na Colônia, o que não impedia a existência de tipografias clandestinas e a circulação de manuscritos com o sentido fazer proliferar idéias e opiniões ${ }^{2}$. Portanto, razões de natureza material mais concretas não explicam por si só o chamado atraso brasileiro em relação as outras colônias da América Espanhola no que diz respeito à implantação da impressão.

Há que se acrescentar uma expectativa, uma mentalidade, um desejo de natureza cultural que ultrapassa as fronteiras das razões mais evidentes de natureza política ou econômica. A chegada da Família Real, em 1808, de fato possibilitou o desenvolvimento da cidade, ampliando o universo populacional, entre outras mu-

${ }^{1}$ Em relação à primeira tendência cf. por exemplo a Melo (1976). Esse estudo é um clássico da história da imprensa brasileira no que diz respeito à explicação por causas da implantação tardia no território brasileiro. No que diz respeito à segunda interpretação, citamos o estudo de Guirado (2001) e Rizzini (1977). Também Bahia (1990) reproduz essa idéia do "jornalismo brasileiro anterior à letra de forma" como sendo a carta, a sátira, o panfleto, entre outras formas de comunicação escrita ou oral.

${ }^{2}$ Rizzini (1977) é prodigo nos exemplos dos manuscritos que aqui circulavam e na descrição das tentativas de introdução do prelo no Brasil, alinhando exaustivamente dados sobre os ensaios de implantação de tipografias antes da chegada de Dom João VI. 
danças, materializando condições mínimas indispensáveis para a necessidade de circulação de idéias de maneira mais ampla. Tal como aconteceu com a Europa Ocidental, a partir do século XIII, quando as novas cidades comerciais constituiram uma nova ordem social, levando à criação de novos sistemas de trocas, também aqui a abertura comercial, a instalação da burocracia oficial e a transferência da Família Real e de seu séquito produziram mudanças econômicas, sociais, políticas e, sobretudo, culturais. Na trilha da troca de mercadorias se estabelece também aqui a troca de informações.

A existência de informações manuscritas e da impressão clandestina, entretanto, não permitem dizer que existissem imprensa e jornalismo. Só existe imprensa no sentido estrito do termo a partir do momento em que a transmissão de informações regular se torna pública, ou seja, accessível ao público em geral. Até então as novidades ou opiniões publicadas, sem qualquer regularidade, não eram tranformadas em notícias. Existia troca de informações, mas não existia imprensa. Só existe imprensa também quando a idéia do público como uma espécie de abstração-concreta se torna o desejo dominante das publicações. Não importa que tipo de público: se os próprios jornalistas, se os poderosos do Reino, se os comerciantes e os militares de alta patente. Há jornalismo quando há publicização no sentido mais amplo do termo.

Portanto, o terceiro grupo de estudos que atribui o substantivo imprensa a uma extensa gama de escritos - de cartas privadas a inscrições eventuais - não se sustenta teoricamente, uma vez que não há nesses textos a característica mais evidente de relação com a esfera pública ativa.

A Gazeta do Rio de Janeiro (1808-1822) inaugurou a impressão no Brasil e a circulação regular de periódicos que aqui passaram a ser impressos e se tornaram, gradativamente, accessíveis a um público mais amplo. Junto com ela vieram outras publicações: livros, opúsculos, livretos, jornais, boletins e outros impressos clandestinos, como o Correio Braziliense (1808-1822). Criam-se condições para que a troca de informações saísse da esfera privada para o âmbito público. Há a necessidade política e burocrática de ampliar a comunicação para um território mais amplo e entre um maior número de pessoas. Daí para a necessidade de adesão, aprovação, publicização será só questão de tempo.

Mais além dessas condições políticas e econômicas, era preciso que se desenvolvesse uma mentalidade num público mais amplo sobre o que eram, de fato, esses períodicos que aqui circulavam de maneira ainda restrita. Um longo período foi necessário para que a imprensa ocupasse lugar efetivo no jogo político das idéias que circulavam na corte. Apenas após o término da censura, em 1821, seriam criadas condições para a proliferação de jornais,

\section{Espécie de} abstração-concreta se torna o desejo dominante das publicações. Há jornalismo quando há publicização no sentido mais amplo do termo 
inclusive nas províncias as mais distantes do Rio de Janeiro. Mas seriam necessários alguns decênios para que o cotidiano dos jornais fizesse gradativamente parte do universo oral/letrado de uma população mais vasta. A teia das notícias era construída, sobretudo, pela rede de informações verbais, que podiam ter origem nas letras impressas, as quais eram retransmitidas oralmente a outros ou diretamente pela conversa oriunda dos ambientes privados. Ao mesmo tempo, as letras impressas passam a se nutrir do jogo das práticas orais.

Somente uma mentalidade abstrata pode atribuir valor efetivo a algo imaterial como idéias que circulam sob a forma de jornais. Não bastam, portanto, condições econômicas e políticas concretas. Para existir a imprensa e se atribuir a ela o valor de transmissora de opinião e informação é preciso que se desenvolva essa mentalidade abstrata. Assim, se os portugueses que aqui aportaram em 1808 já traziam essa disposição, seria necessário ainda um longo período para que o valor abstrato da imprensa se esparramasse pelas cidades, criando efetivamente um público ávido por informações. Não era tão somente o analfabetismo que impedia a explosão da imprensa. Numa sociedade oralizada por excelência, as letras impressas foram sempre mais ouvidas que lidas.

\section{Nos tempos da Gazeta}

Os estudos sobre esse período de gênese da imprensa brasileira são pródigos em descrições curiosas sobre o local onde funcionava e a forma como era impresso o primeiro jornal brasileiro. Nomes e datas se sucedem e assim ficamos sabendo que a Impressão Régia, onde se imprimia a Gazeta, ficava na Rua do Passeio, no Rio de Janeiro, na casa de um tal Conde da Barca, que trouxera na bagagem da Família Real prelos e material tipográfico, o que possibilitou a impressão do novo jornal, cujo primeiro número circulou em 10 de setembro de 1808.

A rigor, a Gazeta do Rio de Janeiro era o jornal oficial da corte de Dom João, que saía diretamente dos prelos da Impressão Régia, a quem competia o monopólio da impressão de qualquer obra tipográfica no país, o que não impedia a inclusão nesse periódico de informações de interesse mais amplo para o público a que se dirigia, como veremos mais adiante. $\mathrm{O}$ fato de ser impresso sob a égide da Coroa Portuguesa não fazia dela menos jornal. As idéias daquele tempo e lugar, as formas como se instauravam o jornalismo na Colônia, as fontes e as redes de informação, as materialidades do impresso e as formas de leitura, tudo isso pode ser descortinado visualizando essas páginas impressas.

A imprensa que servia às intenções da administração colonial, publicando edições ordinárias e outras extraordinárias, deixou
Seria necessário ainda um longo período para que o valor abstrato da imprensa se esparramasse pelas cidades, criando efetivamente um público ávido por informações 
como restos e vestígios do século XIX muito da cultura oral-letrada que se espraiava pelo Reino de Portugal e Algarves. Ao lado das notícias da guerra napoleônica e de outras informações d'além mar, as que tinham maior primazia, figuravam informações cotidianas, impressões dos leitores, informando inclusive sobre as formas de divulgação e a rede de informação que existiam nas cidades. Sendo um sistema útil aos interesses do poder e sendo concessão do Estado a quem competia difundir por suas páginas aquilo que era considerado relevante, era também uma gazeta no sentido lato do termo. Até 1820, será o único jornal (ao lado da Idade d'Ouro do Brasil, publicado na Bahia) a ter oficialmente licença para impressão.

Alguns autores fazem uma distinção entre tipos de períodicos que circulavam no início do século XIX: as gazetas e os jornais, sendo que alguns impressos se auto-denominavam compiladores. Tanto os primeiros, como os segundos faziam das notícias que circulavam originalmente nos jornais estrangeiros mola mestra para a divulgação dos temas da atualidade. Para esses autores, o fato de as gazetas deterem o caráter oficial, já que eram publicadas sob o regime de concessão e privilégios da Imprensa Régia, limitava o conteúdo de suas publicações às notícias de interesse do Estado. Já os jornais privilegiavam as notícias de interesse de um público que se queria mais amplo (Silva, 2007).

Entretanto, olhando mais detidamente esses impressos podese observar que essa divisão não era tão rígida. Um olhar mais acurado mostra ainda o quanto valia a divulgação de fatos e informações já transmitidas por outros periódicos: todos copilavam notícias já publicadas em outros lugares e países e, dessa forma, podiam também se autodenominar "Compiladores" ou "Recompolidadores". Havia, a rigor, uma rede de textos que circulava entre esses periódicos, fazendo com que de suas páginas notícias das gazetas de Lisboa, espanhola, do Times de Londres, do Courrier ou do Journal de Paris, dos jornais da Áustria, da Saxonia e de terras ainda mais distantes, ou mesmo do Correio Braziliense, entre dezenas de outras publicações estrangeiras, fossem republicadas nesses periódicos que inauguram a imprensa brasileira.

Além dessa fonte de notícias, recolhiam os fatos e as informações, que possivelmente interessariam ao público, das redes de boatos e conversas que chegavam pelos navios, ou "por ouvir dizer", "por se falar", "por chegar aos nossos ouvidos", entre dezenas de outras expressões que dão conta também da contaminação do mundo oral nas letras impressas.

$\mathrm{Na}$ cidade do Rio de Janeiro, cujas imagens desse tempo teimam em fazer parte das reconstruções históricas, construindo formas cristalizadas de ver rostos, ruas e prédios, onde se destacam aglomerados e a lógica, aos olhos de hoje, da desordem ur-

Alguns autores
fazem uma
distinção entre
tipos de períodicos
que circulavam no
início do século
XIX: as gazetas
e os jornais,
sendo que alguns
impressos se auto-
denominavam
compiladores

Alguns autores

fazem uma

distinção entre

tipos de períodicos

início do século

XIX: as gazetas

e os jornais,

sendo que alguns

denominavam

compiladores 
bana, circulavam, portanto, jornais de terras distantes que aqui chegavam e eram fontes de informação para os impressos que começavam a sair dos prelos brasileiros. Aqui também circulavam, de maneira clandestina, os periódicos tidos como malditos aos olhos da Coroa Portuguesa, pelas críticas que faziam abertamente ao regime.

O mais famoso deles - na construção a posteriori do tempo de antes - é, sem dúvida, o Correio Braziliense. Nas reconstruções e interpretações históricas realizadas no presente, Hipólito José da Costa, o seu idealizador e editor, é elevado à condição de verdadeiro jornalista. Aquele que de maneira destemida publicava críticas ao sistema colonial, sendo responsável por um "jornalismo desassombrado e persistente" (Bahia, 1990: 25). Mesmo publicações mais atuais referendam o "real pioneirismo em termos do jornalismo no país de Hipólito José da Costa”, ainda que destacando eventuais controvérsias e alertando para interpretações baseadas em visões anacrônicas. Esses autores enfatizam também o "prestígio" do jornal em razão de seu caráter crítico e bem informado, ainda que não saibamos como dimensionar essa opinião (Romancini; Lago, 2007: 25). A rigor, é por comparação com a Gazeta, tachada como jornal oficial, que o Correio é caracterizado. Além disso, usa-se parâmetros do mundo contemporâneo para analisar um mundo há muito esfumaçado na poeira do tempo.

Pelas diferenças que são estabelecidas em relação aos dois periódicos - a Gazeta caracterizada como jornalismo aúlico e o Correio como jornal combativo - configura-se uma mítica de dois modelos para o jornalismo brasileiro a partir desse ponto inicial, gênese de uma história. Tal como nos primórdios da imprensa brasileira, numa linha evolutiva desse jornalismo, ainda hoje este seria - por uma questão de origem - enquadrado nessas duas formulações: de um lado o jornalismo dependente dos favores oficiais, não afeto a controvérsias, que se coloca ao lado dos que estão no poder, e de outro o jornalismo de combate. Assim, essa interpretação histórica referenda valores e modelos que servem a uma tipologia da profissão que é mais de ordem mítica do que de ordem histórica.

Os textos com pretensão de recuperar o passado tal como se deu são também tributários, a maioria das vezes, da idéia de início primordial. É preciso recuperar a grande narrativa - a narrativa do tempo fundamental onde tudo começou - para, instaurando o início, tal como na mitologia judaico-cristã, seguir, a partir daí, a história. As narrativas históricas, neste sentido, são dependentes da narrativa primordial do mundo e de outro mito: o de seu próprio início.

Se partirmos da premissa que a história é narrativa - não po- 
dendo ser nada além de narrativa -, o que se faz quando se escreve a história é construir um texto verossímil, com o objetivo de arranjar de maneira sistemática os incidentes da vida (Ricoeur, 1995: 37).

Seguindo o pensamento de Frank Kermode (1966), há que se relacionar o desejo existente no universo do discurso de completar as narrativas a partir da inclusão do tema apocalíptico, como fim, e o da gênese, como possibilidade de começo absoluto. A história se por um lado tem dificuldade em encerrar suas próprias narrativas, é dependente da idéia, como já enfatizamos, de um início fundamental: a gênese.

O mito do apocalipse e da gênese, segundo Kermode (op. cit.), foram os que mais contribuíram para estruturar as expectativas cristãs. Se a idéia de fim do mundo vem, no caso da escrita do mundo judaico-cristão, do apocalipse, que coloca um ponto final em qualquer história, também neste mesmo círculo de idéias é fundamental a construção de um tempo primordial verdadeiro: um início - a gênese - sem o qual não se poderia começar nenhuma história. A Bíblia se constitui, para o autor, na intriga grandiosa da história do mundo e cada narrativa (intrigas literárias ou históricas) é uma espécie de miniatura dessa grande intriga, que caminha da gênese ao apocalipse.

Assim, toda história se inicia num começo primordial, numa espécie de gênese grandiosa da narrativa. Mas a história tradicional precisa ir mais além: é preciso instaurar o começo verdadeiro, o mito primordial dos tempos fundadores. Essa mesma história, que se inicia no tempo fundador (o marco zero), caminha em direção a um fim, por meio de contingências e peripécias (Ricoeur, 1994: passim). Toda história verossímil deve ter começo, meio e fim. É preciso que se consiga seguir a história.

Mas o fim não pode significar o apagamento da narrativa. Assim, o final transforma-se de iminente em imanente. Constrói-se não a imagem do fim último e inexpugnável (o apocalipse), mas os últimos tempos - tempos de terror, de decadência, mas também de renovação. É dessa forma que o mito apocalíptico na história se transforma no mito da crise (Ricoeur, 1995: 35-40).

Se a narrativa da crise é facilmente identificável nas narrativas literárias, também nas construções históricas o que se privilegia são os momentos que marcam rupturas: crises que significam quase sempre renovação. No caso da história da imprensa, essa marca é considerável.

Os jornais instauram momentos particulares de uma formação histórica específica, mapeados em termos de "início incipiente", desenvolvimento "particular", construções de um novo tempo governado pela lógica da tecnicidade, implantação de uma im- 
prensa de massa e, assim por diante, numa sucessão de tempos infinitos e particulares.

No caso da imprensa brasileira, depois da gênese - instaurada pela implantação da imprensa no país com a vinda da Família Real em 1808 - passa-se a um período em que a imprensa divide-se entre oficial e "oficiosa": é o tempo da supremacia do jornalismo como representante da fala oficial do poder político. $\mathrm{Na}$ sucessão de tempos dessa história, a fundação da Aurora Fluminense, por Evaristo da Veiga, e do Jornal do Commercio (e de seu antecessor direto, o Spectador Brasileiro), em 1827, marcaria outro tempo singular: o início de uma imprensa que buscaria na construção de um discurso de cunho político a base de sua produção editorial. No momento seguinte, irrompem os debates em torno da questão republicana e abolicionista e o jornalismo será - nessas interpretações - palco fundamental para a ampliação dos grandes embates discursivos nacionais. Ampliando a nova cultura política, os jornais amplificam as discussões, construindo idéias dominantes num jornalismo de viés exclusivamente opinativo. Nesse cenário, ganha uma interpretação particular o jornalismo abolicionista: se para alguns autores sua atuação foi fundamental, para outros o poder de difusão restrito desses periódicos construíram mais uma importância simbólica do que a que de fato exerceram na sociedade. E, finalmente, nessa história sujeita a interpretações particulares emergem as tecnologias de um novo século e as transformações da imprensa na cidade, capitaneadas pelas transformações da alvorada do século $\mathrm{XX}^{3}$.

$\mathrm{O}$ século XX é objeto de profícuas e díspares interpretações, e multiplicam-se as análises que particularizam os jornais e os processos singulares, em torno de nomes e periódicos que tiveram "certa importância”, como já assinalamos ${ }^{4}$.

Em todas essas reconstruções domina, portanto, a idéia de rupturas singulares, tempos particulares, processos emblemáticos: a noção de crise fornece a senha para a construção de uma história que se quer verdadeira, mas é - sempre - uma interpretação entre muitas possíveis. Olhando essas publicações podemos chegar a outras interpretações sobre esses primeiros impressos que aqui circulavam.

Paul Veyne, num texto que já se tornou clássico, "Como se escreve a história" (1971), diz textualmente que a história é uma ciência por demais "sublunar" para ser explicada por leis. Ao se fazer história deve-se diminuir a pretensão explicativa e, ao mesmo tempo, elevar a sua capacidade narrativa. Para Veyne (op. cit.: 90), a história é uma "noção livresca e não um existencial; é a organização pela inteligência de dados que se relacionam a uma temporalidade e que não a do Dasein". Portanto, não há fundamento existencial na construção da história.

${ }^{3}$ Sobre esse modelo de historicidade cf. o próprio livro de Nelson Werneck Sodré (1966) e o trabalho também exaustivamente citado de Juarez Bahia (1990), apenas para citar duas das obras mais conhecidas.

${ }^{4}$ São inúmeros os trabalhos que se dedicam a estudar a imprensa brasileira no século XX. Para uma perspectiva particular cf. Barbosa (2007). 
Mas o que leva um acontecimento a ser considerado como histórico? O que faz com que um objeto, uma particularidade, um fato passado seja alvo de reflexão histórica? Não é a singularidade do acontecimento. Para Veyne, é o fato de figurar numa intriga. Qualquer acontecimento, nesse sentido, pode ser histórico, cabendo ao interpretante no presente elevá-lo a essa categoria a partir da sua compreensão/explicação particular. Um acontecimento histórico é aquilo que já foi narrado e pode ser re-narrado.

Assim, não basta tentar trazer o passado para o presente. É preciso, através dos documentos, nessa lógica histórica onde o início primordial fornece uma espécie de senha para se ingressar neste universo, mostrar quando tudo começou. A história passa a ser validada pela idéia de início primordial, espécie de narrativa mítica, que instaura o momento fabuloso do começo. A idéia de gênese, portanto, carrega em si mesma um sentido supra-histórico. A gênese, mais do que um modelo arquétipo e mais do que a exemplaridade, indica um início primordial e singular. Nenhuma gênese - ainda que todas sejam caracterizadas pelo começo exemplar - é igual à outra. Cada uma nasce de uma forma. E como tempo de antes é acima de tudo um mito no sentido mais completo do termo: ao mesmo tempo ficção, sistema de explicação e mensagem mobilizadora. Mas a idéia de gênese, além da mítica do tempo de antes, contém também a noção de algo absoluto, completamente liberto da relação posterior de sucessão incluída na ordem do tempo. A gênese é o começo particular que instaura não apenas uma nova ordem política e social, mas o ponto zero da própria reflexão histórica.

Mas a história lida, sobretudo, com a construção narrativa. E neste sentido deve ser vista como permanente reconstrução, sujeita a re-interpretações, mudanças de enfoque, compreensão que induz a explicar. Afinal, compreender é, sempre, explicar melhor.

A razão de se buscar o ponto inicial de um processo está, pois, mais para a construção de uma ordem mítica, do que pertence ao universo da construção histórica. Afinal seguir a história é sempre recontar outra história.

\section{Um novo sistema de comunicação}

As descrições tradicionais da história da imprensa que se referem à Gazeta do Rio de Janeiro habitualmente enfatizam o seu caráter oficial, isto é, o fato de publicar fatos e informações do interesse da Coroa Portuguesa. Assim, temos a impressão de que a Gazeta era fértil na publicação de decretos, avisos, editos e outros textos de interesse do Reino Português. Que nela não se publicavam outras informações. Mas, olhando detidamente o periódico,

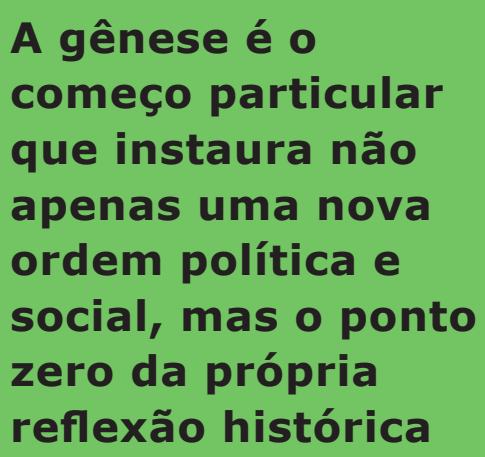

A gênese é o começo particular que instaura não apenas uma nova ordem política e social, mas o ponto reflexão histórica 
saltam de suas páginas múltiplas fontes de informação, formando redes de notícias do início do século XIX, indicando também a forma como essas notícias passavam do mundo oral para o mundo do impresso.

Cartas vindas pelos navios que aqui aportavam e periódicos da Europa que chegavam ao Cais Pharoux na carga desses mesmos navios traziam as principais notícias que seriam publicadas. A sociedade desenvolvia múltiplas formas de se comunicar e, a partir daí, de buscar e reunir informações. Havia, portanto, um sistema de comunicação na cidade do Rio de Janeiro que possibilitava a impressão das notícias na Gazeta.

Esse sistema começava na então longínqua Europa. De lá, pessoas que embarcavam e aqui aportavam transbordavam, "por se ouvir dizer", de informações a cidade. Os navios traziam também cartas que eram transformadas de manuscritos em sínteses impressas e que seriam publicadas no periódico. Mas os navios traziam, principalmente, as folhas européias cujas notícias eram recopiladas, sintetizadas e novamente publicadas na cidade do Rio de Janeiro. Os boatos se transformavam em fontes privilegiadas de informação. Mas era preciso descobrir o que de fato estava acontecendo. E os jornais já impressos em terras distantes davam a senha para a transformação das histórias do mundo oral em notícias. E quando ganhavam a nova materialidade era como se tivesse sido desfeita a imprecisão das informações. As vozes que corriam e que divulgavam notícias ainda que "merecessem confirmação" eram agora notícias impressas.

O primeiro número da Gazeta do Rio de Janeiro, editado em uma coluna, com textos reagrupados em blocos de informação semelhantes - primeiro aqueles que tiveram origem em Londres no dia 12 de junho, depois os que lá foram publicados em 16 de junho, em seguida os que se originaram no Rio de Janeiro no dia da publicação daquele número e, por último, informações sobre a venda do próprio periódico e uma nota sob a rubrica Notícia sobre o fato de estar no prelo a Memória Histórica da Invasão dos Franceses a Portugal em 1807 - é pródigo em exemplos que permite remontar esse sistema de comunicação.

Primeiro as notícias "por via da França”. Em seguida, as folhas de Hamburgo e de Altona, que já haviam se transformado em impressos vindos por Gottemburgo:

Chegarão-nos esta manhã folhas de Hamburgo, de Altona até 17 do corrente. Estas últimas anunciam que os Janizaros em Constantinopla se declararão contra a França e a favor da Inglaterra; porém que o tumulto tinha se apaziguado.

O texto seguinte indicava as pausas na leitura e a mudança de assunto marcadas graficamente por um travessão, para informar que

\section{Olhando \\ detidamente 0 periódico, saltam de suas páginas múltiplas fontes de informação indicando também a forma como essas notícias passavam do mundo oral para o mundo do impresso}


Hamburgo está tão exaurido pela passagem de tropas que em muitas casas não se acha já uma côdea de pão, nem uma cama. Quase todo o Hannover se acha nesta deplorável situação.

Nova marcação de mudança de assunto e outra informação: "5000 homens de tropas francesas, que estão na Itália, tiveram ordem de marchar para Espanha" (Gazeta, nº 1, 10 set. 1808: 1).

Portanto, dos jornais já lidos e copilados que foram publicados em outras cidades européias e que chegaram a Gottemburgo, lá se transformando em notícias, tornavam a sintetizar as informações e as republicavam, enfatizando primeiramente aquelas que diziam respeito ao conflito europeu desencadeado pelos franceses e as suas conseqüências maléficas para o mundo. Chama a atenção, na síntese que realizavam, as notícias poderem ser divulgadas em poucas linhas e as indicações gráficas de marcação de mudança de assunto. Essas materialidades indicariam um modo de leitura de um público ainda pouco afeto às letras impressas?

O sistema de comunicação do início do século XIX fazia transbordar primeiramente pelo mundo notícias de múltiplos periódicos, como uma rede de textos, lidos e relidos para serem depois sintetizados em pequenas notas ou em grandes textos, dependendo do espaço e do interesse que se tinha naquela informação. O caminho começava no lugar de onde a informação provinha. Dali dava voltas em diversos países e oficinas se transformando em impressos que eram embarcados em navios que cruzavam os oceanos. Desses navios seguiam para outros países, onde em outras oficinas impressoras ganhavam novas formas para, finalmente, serem impressos e distribuídos a milhares de quilômetros de distância de onde a notícia tinha se originado. As notícias impressas no início do século XIX eram quase sempre de quarta ou de quinta natureza.

Mas não eram apenas os jornais de outros países as fontes privilegiadas de informação. Podiam retirar as notícias de pedaços de cartas que também vinham ou eram escritas a bordo dos navios. No mesmo dia 10 de setembro, a Gazeta publica o "Extrato de uma carta escrita a bordo da Statira", em 16 de junho, que reproduzia uma informação oral transmitida a alguém que a transformou em letras manuscritas e, posteriormente, em impresso, para ser três meses depois re-transformada em outro impresso, agora em terras ainda mais distantes do lugar de onde se originara. $\mathrm{O}$ circuito da comunicação que terminou com a publicação da informação pela Gazeta e, sobretudo, pela interpretação que dela fizeram os leitores, transformados em anônimos pelo correr do tempo, começara com uma informação oral de um oficial espanhol. Não importava o nome, apenas a informação que transmitira.

Essa informação se transforma em manuscrito: uma carta es-
As notícias impressas no início do século XIX eram quase sempre de quarta ou de quinta natureza 
crita a bordo de um navio. E em seguida se transmuta em notícia num jornal londrino. Como essa carta foi parar nas mãos do redator? Não sabemos e não saberemos. O tempo apagou essa informação. Mas, a carta, ou pelo menos a informação que dela extraiu o redator da Gazeta, chegou até nós sob a forma de letras impressas. O mundo oral está inscrito na maioria das informações impressas do século XIX.

Londres a 16 de junho. Extrato de uma carta escrita a bordo da Statira. Segundo o que nos disse o oficial espanhol, que levamos a Lorde Gambier, o povo espanhol faz todo o possível para sacudir o jugo francês. As províncias de Astúrias, Leão e outras adjacentes armarão oito mil homens, em cujo número se compreendem vários mil de tropa regular tanto de pé, como de cavalo (Gazeta, $\mathrm{n}^{\circ}$ 1, 10 set. 1808: 1).

A rede de informações que permitia a proliferação das notícias na Gazeta do Rio de Janeiro percorria um circuito que a maioria das vezes começava no interior dos navios que aportavam no cais Pharoux. Sejam as cartas que lá se escreviam, sejam os periódicos que transportavam, sejam os fatos contados pelos que lá estavam. Um fragata inglesa que entrara "neste Porto a 19 do passado" podia trazer "as importantes notícias que se seguem" (id.: 4).

As conversas ao pé do ouvido e as informações passadas de uns para outros eram também fontes privilegiadas de informação. Pessoas vindas de províncias distantes ou de países longínquos faziam "correr notícias" ou "correr vozes" de tal forma que davam a senha para a transformação do mundo oral em letras impressas.

Correu aqui notícia vinda por pedestres de Goiás; que os franceses haviam feito um desembarque no Pará com aparências de amizade, o Capitão General os rechaçara completamente, ficando vivos só os prisioneiros: porém isso merece confirmação (Gazeta, $\mathrm{n}^{\circ} 1,10$ set. 1808: 4).

Como os "pedestres de Goiás" fizeram as notícias chegarem aos ouvidos do redator da Gazeta? Certamente por um circuito de comunicação que inclui formas de sociabilidades e que indicam a transmissão de uma informação a outro e a outros, numa rede infinita de transmissão oral. Quanto tempo levou essa notícia para vir na boca de pessoas que saíram a pé e aportaram na Corte? Notícias que mesmo que ainda merecessem confirmação, mereceram a publicação. A lógica da produção noticiosa do início do século XIX, ainda longe da idéia de veracidade e fidedignidade da informação, era a possibilidade e a rapidez do noticiário. As notícias corriam ou corriam as vozes que se transformavam em notícias. 
Igualmente correu voz que um corsário frances desembarcaria as 20 horas na Costa do Pará ou Maranhão para procurar a força mantimentos e que toda essa gente fora morta ou feita prisioneira; tendo feito-se a vela o Corsário desembaraçado do porto em que tocaria, pois Cayena se diz bloqueada por duas Fragatas inglesas (id., p. 4. Grifos nossos).

O uso repetido do verbo "correr" indica uma predisposição para os fatos novos que ocorriam no mundo. A notícia era a novidade, ainda que naquele longínquo ano de 1808 o novo era o que fora noticiado três meses antes em terras européias. As notícias de um mundo distante tinham prevalência no noticiário. Mas os boatos ganhavam destaque na medida em que produziam a corrida pela novidade. Assim, as notícias também "andavam de boca em boca".

Rio de Janeiro. Como anda de boca em boca e se acredita firmemente a declaração da guerra de Rússia contra a França, de mãos dadas com a Prússia, em socorro de Áustria, e também se fala de uma batalha de 11 e 12 de setembro entre os franceses e austríacos em que estes ficaram vencedores, tudo extraído, dizem, das folhas inglezas; nós, se bem não garantimos a verdade destas notícias, pois que não as achamos confirmadas, nem mesmo anunciadas em muitas folhas inglesas daquela data, que temos debaixo dos olhos; contudo nesse número transcrevemos palavra por palavra o folheto impresso, que veio de Lisboa, e que deu causa a esta persuasão, fazendo os mais ardentes votos para que ele se verifique em toda a sua plenitude e ainda muito mais. (Gazeta, $\mathrm{n}^{\mathrm{o}}$ 136, 30 dez. 1809. Grifos nossos.)

A notícia anterior fornece muitas informações não só sobre a forma como as notícias eram construídas - isto é, pela prevalência de duas ordens de informação, as que "andavam de boca em boca", o que possibilitava um burburinho continuado de vozes na cidade, e as que se confirmavam a partir da sua transformação em letras impressas, razão pela qual era preciso "confirmar" ou vê-las "anunciadas em muitas folhas inglesas" - como também indica o mundo cotidiano do redator daquelas publicações.

Lendo em profusão - "muitas folhas" estavam "debaixo de seus olhos" - tinham, evidentemente, particular interesse naquelas que eram do mundo aliado. A opção política dos periódicos era determinante na confirmação da veracidade da informação. Mas mesmo se não encontrasse a informação, o mundo da impressão fornecia uma espécie de senha para a entrada no mundo noticioso. É por essa razão que, mesmo sem achar confirmação da notícia nas folhas inglesas, a Gazeta transcreveria "palavra por palavra" o folheto impresso que veio de Lisboa.
A notícia era a novidade, ainda que naquele longínquo ano de 1808 o novo era o que fora noticiado três meses antes em terras européias 
Imaginamos esse mundo do início do século XIX como um lugar onde a informação e o novo não tivessem muita importância. Fazemos isso, ao lançar nossos valores a esse mundo desconhecido e estranho. Mas observando os ecos que o passado deixou no presente, pode-se remontar a densa rede de comunicação que existia na cidade do Rio de Janeiro. Havia tantos modos de comunicação que remontar essa trama é semelhante a refazer um verdadeiro quebra-cabeça. Remontando-o, montamos o circuito de comunicação daquele longínquo 1808.

Esse circuito começa na produção da notícia, que, como vimos, se inicia na transformação do fato em algo digno de ser publicizado. Alguém falou, alguém escreveu, alguém publicou. Aqui o redator da publicação escutaria, leria, sintetizaria, escreveria e re-imprimiria. Havia, portanto, um múltiplo jogo interpretativo em todas as notícias publicadas. Cartas, jornais, boatos, conversas eram as fontes de informação que se transformavam em notícias nas páginas da Gazeta. Havia também uma seleção e uma hierarquização: habitualmente primeiro as notícias de terras distantes, depois as informações do Rio de Janeiro. Havia o mundo e a cidade que eram ofertados à apropriação crítica do público.

Desde o primeiro número a Gazeta se dirige a este leitor hoje anônimo: o público. Para ele informam com destaque que "a Gazeta do Rio de Janeiro deve sair todos os sábados pela manhã". Informam também onde se vende, quanto custa, como se faz para ser assinante, que esses assinantes a receberão em suas casas o jornal e que o jornal publicará anúncios.

Faz-se saber ao público: que a Gazeta do Rio de Janeiro deve sair todos os sábados pela manhã: que se vende nesta Corte em Paulo Martin, Filho, Mercador de Livros no fim da Rua da Quitanda ao preço de 80 réis: Que as pessoas que quiserem ser assinantes deverão dar os seus nomes e moradas na sobredita casa, pagando logo os seis meses a 1:900 réis; e lhes serão remetidas as folhas as suas casas no sábado pela manhã: que na mesma Gazeta se porão quaisquer anúncios, que se queiram fazer; devendo estar na quarta feira no fim da tarde na Impressão Régia (id.: 4).

A deficiência nos sistemas de transporte e a indicação de que os assinantes receberiam em casa o periódico faz supor também que a maioria dos assinantes se concentrava no centro administrativo da Colônia. E os anúncios publicados nos números seguintes materializam os lugares onde habitavam os leitores dessa publicação: Rua dos Passos, Santa Rita, por detrás do Império da Lapa, Rua das Marrecas, Rua Direita, Rua da Quitanda e adjacências.
Havia tantos modos

de comunicação

que remontar essa

trama é semelhante

a refazer um

verdadeiro

quebra-cabeça.

Remontando-o,

montamos o circuito

de comunicação

daquele longínquo

1808 
Os anunciantes são antes de tudo leitores, como também o era o redator de $A$ Gazeta que lia em profusão as notícias publicadas pelos jornais europeus. Inicialmente proliferam os anúncios de venda de casas. Depois os leilões, os do comércio em geral, mostrando claramente o crescimento da cidade. Quase ao mesmo tempo se multiplicam os anúncios dando conta da existência do cruel sistema de exploração escravista.

Quem quiser comprar uma morada de casas de sobrado com frente para Santa Rita fale com Anna Joaquina da Silva, que mora nas mesmas casas, ou com o Capitão Francisco Pereira de Mesquita que tem ordem para as vender (id., n. 2, 17 set. 1808: 4).

Podemos supor que Anna Joaquina da Silva, que morava naquelas casas, não soubesse ler, e que o Capitão Francisco Pereira de Mesquita, leitor de a Gazeta, foi quem mandara incluir o anúncio no periódico. Mesmo sem ler ou escrever, Anna Joaquina era leitora por ouvir dizer. O Capitão certamente a informara sobre a venda das casas e que pessoas iriam até lá para ver as moradas. Imagens e imaginação sobre um tempo que só pode ser recuperado como re-interpretação.

Outras moradas de casas são anunciadas nos números seguintes, bem como há a preocupação de avisar ao público a edição das chamadas Gazetas Extraordinárias, a primeira datada de 14 de setembro. "Avisa-se o público que segunda feira próxima haverá Gazeta extraordinária”, informam novamente em 3 de dezembro de 1808.

A partir do número dois, de 17 de setembro de 1808, a Gazeta passa a ser bissemanal, saindo também às quartas-feiras, razão pela qual os assinantes deverão "assistir com o dobro da primeira assinatura". E sempre que houvesse uma razão para publicar maior número de folhas, uma edição extraordinária saía dos prelos da Impressão Régia. Só em 1808 publicaram 19 números extraordinários. Havia muita informação que "corria de boa em boca" e "a passos largos". Não apenas as notas oficiais, mas notícias sobre um mundo distante que se fazia mais próximo. No número 24 , de 3 de dezembro de 1808, informam que as notícias de Londres se originaram de uma "carta de Amsterdã datada de 28 do passado". Mas as notícias também faziam o caminho inverso.

Londres. 11 de agosto. Pelos navios ultimamente chegados do Brasil recebemos um manifesto publicado por ordem de Sua Alteza Real o Príncipe Regente motivado pelas circunstâncias que fizeram transferir o assento do Governo para a América (Gazeta, $\mathrm{n}^{\circ}$ 24, 3 dez. 1808: 1).
A deficiência nos sistemas de transporte e a indicação de que os assinantes receberiam em casa o periódico faz supor também que a maioria dos assinantes se concentrava no centro administrativo da Colônia 
No decorrer de 1808 e ao longo de 1809, a diversidade dos anúncios indica o poder crescente de difusão do periódico. Ao lado dos tradicionais avisos de vendas de inúmeras mercadorias, de arrendamentos e de leilões, outros leitores diretos ou indiretos informavam a perda de objetos materiais ou humano tratado como mercadoria. Uma espingarda faltou a Bento José de Carvalho, o que o motivou o "morador ao pé do Trapiche da Cidade" (id., n ${ }^{\circ}$ 32, 31 dez. 1808) a incluir no periódico o anúncio, mas podiam faltar também os escravos que fugiam cotidianamente. A todos se prometiam recompensas ou "alviçaras".

Em 20 de agosto do ano próximo fugiu um escravo preto, por nome Matheus, com os seguintes sinais: rosto grande e redondo, com dois talhos, um por cima da sobrancelha esquerda e outro nas costas, olhos pequenos, estatura ordinária, mãos grandes, dedos grossos e curtos, pés grandes e o corpo grosso. Na Loja da Fazenda de Antonio José Mendes Salgado de Azevedo Guimarães na Rua da Quitanda, nº 61 receberá quem o entregar, além das despesas que tiver feito $12 \$ 800$ réis de alviçaras.

Descritos sempre por suas características físicas, nas quais se sobressaíam as referências às marcas fincadas no corpo (talhos pelo rosto e pelas costas como lembranças fixas dos maus tratos impostos), os escravos eram para aqueles leitores/anunciantes objetos de grande valor. Por Matheus, caracterizado pelos lugares do corpo que existiam em função do seu trabalho braçal - mãos grandes, dedos grossos e curtos, pés grandes e o corpo grosso -, Antonio José Mendes, comerciante e cuja loja da fazenda ficava na Rua da Quitanda no Centro da Cidade e próxima ao Cais Pharoux, pagava $12 \$ 800$ réis, ou seja, quase sete vezes mais do que custava inicialmente a assinatura do periódico por um período de seis meses.

Certamente é quase impossível recuperar a forma como esses leitores liam essas notícias e que motivações os levavam a publicar tais anúncios. Esperavam, é certo, a partir dessa publicização ver recuperadas suas perdas. Antonio José Mendes quis dar publicidade à fuga do escravo e acreditava que algum outro leitor tivesse visto Matheus e o trouxesse de volta. A leitura é sempre uma atividade que pressupõe dar sentido aos signos encaixando-os em estruturas.

Bento José e Antonio Mendes esperavam que a leitura de um outrem fosse positiva para eles: que descortinassem suas perdas para um mundo mais amplo. As interpretações do público, certamente, estavam envelopadas pelo sentido oral das palavras. Um mundo de ouvir dizer, de notícias que corriam, de informações que proliferavam pelas práticas da oralidade e se transmutavam em letras impressas com o mesmo sentido. Era assim que Bento e Antonio acreditavam que as letras impressas corressem léguas

\section{Descritos}

sempre por suas características físicas, nas quais se sobressaíam as referências às marcas fincadas no corpo, os escravos eram para aqueles leitores/ anunciantes objetos de grande valor 
de ouvido em ouvido para trazer de volta o escravo que fugira ou a espingarda que sumira.

Como Robert Darnton (2005: 82) afirma, talvez não faça sentido separar a forma impressa dos modos de comunicação oral e manuscrita nesse mundo do início da impressão. Esse público, seja o assinante habitual da Gazeta, seja o que tomava conhecimento das notícias que ali se publicava também por ouvir dizer, estava entrelaçado num sistema de múltiplos meios nos quais o mundo oral, o mundo dos manuscritos e dos impressos eram intercambiáveis. O que importava era a amplificação das mensagens, não interessando muito a forma como alcançava o público. Havia retro-alimentação e convergência, e não fluxo unidirecional e causalidade linear.

Ainda que pudéssemos pensar que essas notícias que deram início da impressão no país atingissem um público extremamente restrito, quando refletimos sobre as formas de vida e as sociabilidades existentes na cidade, devemos pensar numa mistura de públicos que se cruzavam e andavam lado a lado por toda a parte. Devemos seguir o conselho de Darnton (id.: 83), que enfatiza ser necessário, ao estudar a comunicação, procurar por misturas tanto de ambientes como de meios.

Até 1815 algumas alterações são visíveis nas páginas da publicação. Agora traduzem notícias inteiras extraídas dos periódicos europeus e já produzem sínteses no início das notícias, como que fornecendo um guia de leitura. "Para formar uma idéia adequada da desgraçada condição dos espanhóis que gemem debaixo do acoite da brutalidade francesa, lancem os nossos leitores os olhos ao seguinte artigo de uma folha de Londres de 14 de novembro e que vem na Gazeta de Lisboa n ${ }^{\circ} 159^{\prime \prime}$ (Gazeta, $\mathrm{n}^{\circ}$ 18, 3 mar. 1810). Em 1810 passam a publicar as Notícias Marítimas, isto é, as informações do movimento de entrada e saída dos navios do Porto.

Do ponto de vista gráfico, a principal mudança na materialidade do jornal se dá em 1811. Passa a ser impresso em duas colunas, tornando-se mais largo, para poder incluir maior número de palavras. E com o término do conflito com a França precisam inundar as páginas de notícias com outro teor, e que fossem de interesse do público. A rapidez do desenrolar da guerra euro péia, que obrigava a inclusão de notícias de última hora e que levava a proliferação das Gazetas Extraordinárias, tinha ficado para trás.

Lisboa, 19 de julho. Não queremos demorar ao público a notícia da conclusão da campanha pela capitulação de Paris, que nos trouxe hoje a Gazeta de Madrid de 15 do corrente; e que se publica do modo seguinte. (Gazeta, $\mathrm{n}^{\circ}$ 75, 20 de setembro de 1815.) 
Sem os conflitos bélicos, passam a mesclar as informações transcritas dos jornais da corte com outras que falam da penúria dos deserdados ou das mortes violentas dos perdedores. Essas eram pródigas nas minúcias que materializavam emoções.

Corunha. 12 de outubro. Depois da prisão do General Portier, em Santiago, onde foi metido na cadeia da Inquisição, foi trazido para aqui a 26 de setembro com alguns oficiais do seu partido e enforcado no Campo de la Honra. O defunto General Portier deixou ordem no seu testamento que o seu corpo fosse metido em um caixio, fechado com uma chave e esta fosse entregue a sua mulher, com um lenço molhado com as suas últimas lágrimas, e que quando as circunstâncias o permitissem fosse posto um pantheon com a inscrição seguinte: aqui descansa as cinzas de D. Juan Dias Portier, General dos exércitos espanhóis e que foi feliz em tudo quanto empreendeu contra os inimigos de sua pátria e morreu vítima das dissensões civis. Almas sensíveis! Respeitai as cinzas de um infeliz (Gazeta, $\mathrm{n}^{\circ}$ 9, 31 jan. 1816).

Poderíamos afirmar que este tipo de notícia antecipava as técnicas que seriam desenvolvidas um século mais tarde pelo jornalismo de sensações? As batalhas eram reduzidas às mortes violentas. Mas não bastava informar que o General seria enforcado. Era preciso particularizar a informação com dados que despertassem emoção. Depois de morto no seu testamento, dava conta a notícia, estava expresso que o seu corpo seria fechado a chave num caixio, e o lenço molhado com suas últimas lágrimas seria entregue como lembrança do seu sofrimento e de sua dor a sua mulher. Para terminar, reproduzem o dístico que deveria ser colocado na tumba do morto. "Almas sensíveis! Respeitai as cinzas de um infeliz".

A diversidade e o teor dos anúncios, agora sob a rubrica Avisos, fazem supor a ampliação do público, bem como a notícia de que alguns exemplares, em função da vendagem, tiveram que ser reimpressos. Agora os aluguéis de cavalos "por preço mais cômodo", de pólvora, de rapé e de outros gêneros mais populares figuram ao lado dos anúncios destinados aos abastados do Reino.

Os assinantes passam a ter direito, além das Gazetas Ordinárias e as Extraordinárias, chamadas de Dobradas, à Lista de Despachos, além de um exemplar de "qualquer obra que se haja de distribuir gratuitamente". O mundo dos impressos se alargava paulatinamente (id., $\left.\mathrm{n}^{0} 104,30 \mathrm{dez} 1815\right)$.

As notícias continuam vindo de terras as mais distantes. Zurich, São Petersburgo, Paris, Copenhagen, Berlin, Viena, Nápoles e Bruxelas, entre dezenas de outras cidades européias. Não há mais referência expressa às gazetas de onde retiram as notícias. Com isso dão a impressão de uma onipresença em todos os lugares.

Mas, a mudança mais significativa na materialidade de A Gaze- 
ta ocorre em janeiro de 1822: mudam o titulo para Gazeta do Rio e passam a editar o número e a data do periódico numa única linha por extenso, antes do nome do periódico. Outros ornamentos fazem parte do mesmo número: fios e frisos e flores ladeando o brasão dos Bragança impresso como símbolo do jornal. Nesse último ano de circulação quase todas as notícias são retiradas do Diário do Governo. As Ordens do Dia da Corte também proliferam ao lado das Sessões e Artigos Políticos retirados daquele diário. Por último, fechando o jornal, as Notícias Marítimas e os Avisos. Em 14 de dezembro de 1822, no suplemento ao número 150 noticiam ao público a substituição do periódico pelo Diário do Governo. Estava dada a senha para o a edição do último número do primeiro jornal impresso editado no Brasil.

\section{Referências}

BAHIA, Juarez. Jornal. História e Técnica. História da Imprensa Brasileira. Rio de Janeiro: Ática, 1990.

BARBOSA, Marialva. História Cultural da Imprensa: Brasil (1900-2000). Rio de Janeiro: Mauad, 2007.

DARNTON, Robert. Os dentes falsos de George Washington: Um guia não convencional para o século XVIII. São Paulo: Cia das Letras, 2005.

GUIRADO, Maria Cicília. Relatos do Descobrimento do Brasil: as primeiras reportagens. Lisboa: Instituto Piaget, 2001.

KERMODE, F. The sense of an ending: Studies in the theory of fiction. Londres, Oxford, Nova Iorque: Oxford University Press, 1966.

MELO, José Marques de. Fatores que retardaram o surgimento da imprensa no Brasil. Tese de Doutorado em Jornalismo. ECA/USP, 1976.

RICOEUR, Paul. Tempo e Narrativa, vol. 1 e 2. Campinas: Papirus, 1994 e 1995.

RIZZINI, Carlos. O jornalismo antes da tipografia. São Paulo: Companhia Editora Nacional, 1977.

ROMANCINI, Richard; LAGO, Claudia. História do jornalismo no Brasil. Florianópolis: Insular, 2007.

SILVA, Maria Beatriz Nizza da. A Gazeta do Rio de Janeiro (1808-1822): cultura e sociedade. Rio de Janeiro: EdUERJ, 2007.

SODRÉ, Nelson Werneck. História da imprensa no Brasil. Rio de Janeiro: Civilização Brasileira, 1966.

VEYNE, Paul. Como se escreve a história. Brasília: UNB, 1998. Edição original "Comment on écrit l'histoire”. Paris: Editions du Seuil, 1971.

\section{Fontes Primárias}

Gazeta do Rio de Janeiro - $\mathrm{n}^{\circ} 1$ (10 setembro de 1808) ao Suplemento ao $\mathrm{n}^{\circ}$ 150 (14 de dezembro 1822). 